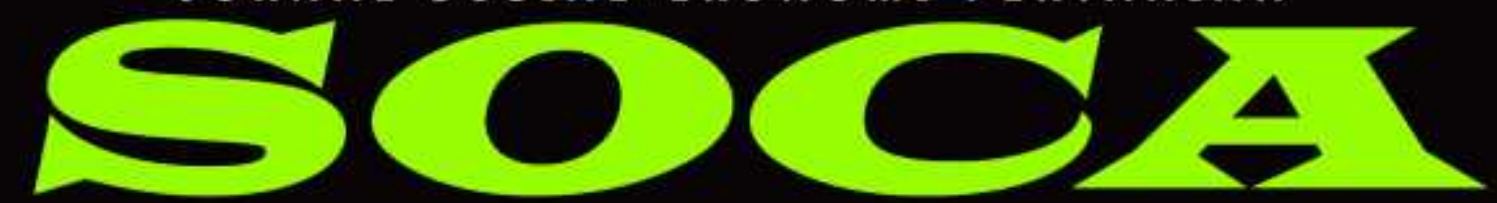

JOURNAL ON SOCIAL ECONOMICS OF AGRICULTURE

Vol.13 No.2 31 Agustus 2019

e-ISSN: 2615-6628

p-ISSN: $1411-7176$

\title{
PERILAKU PETANI KOPI KELOMPOK TANI MAKARTI UTOMO DI DUSUN GENTING DESA GETAS KECAMATAN SINGOROJO KABUPATEN KENDAL
}

\author{
Siti Hajjah Mardiah, Tutik Dalmiyatun dan Sriroso Satmoko \\ Program Studi Agribisnis, Departemen Pertanian, \\ Fakultas Peternakan dan Pertanian, Universitas Diponegoro \\ E-mail: sitihamardiah1997@gmail.com \\ HP: 081229531351
}

\begin{abstract}
ABSTRAK
Kopi merupakan salah satu hasil perkebunan Indonesia yang pemasarannya sudah bertaraf Internasional, namun kopi yang diekspor hanya kopi yang bermutu tinggi. Permasalahan yang terjadi pada komoditas kopi di Indonesia yaitu tidak semua petani kopi mampu menghasilkan kopi bermutu tinggi, sehingga mengakibatkan harga tawar kopi masih rendah. Salah satu faktor yang mempengaruhi mutu kopi yaitu perilaku petani dalam mengelola usahatani kopi, dimana perilaku yang dimaksud terdiri dari pengetahuan, sikap dan keterampilan. Penelitian ini bertujuan untuk mengetahui perilaku petani kopi serta menganalisis pengaruh tingkat pengetahuan, sikap dan keterampilan petani terhadap mutu produksi kopi di Kelompok Tani Makarti Utomo. Penelitian ini dilaksanakan bulan OktoberNovember 2018 berlokasi di Dusun Genting Desa Getas Kecamatan Singorojo Kabupaten Kendal. Metode penelitian menggunakan metode survei dan seluruh anggota kelompok tani digunakan sebagai responden sebanyak 37 petani menggunakan metode sensus. Sumber data diperoleh dari data primer dan sekunder. Metode analisis data menggunakan analisis deskriptif dan regresi linier berganda. Hasil penelitian 1) kelompok Tani Makarti Utomo memiliki tingkat pengetahuan cukup baik, tapi perlu ditingkatkan, tingkat sikap sudah baik karena memiliki kesadaran mutu baik, tingkat keterampilan dalam pengelolaan usahatani kopi sudah cukup baik tapi perlu ditingkatkan dan tingkat mutu kopi cukup baik berdasarkan mutu fisik biji kopi, 2) pengetahuan, sikap dan keterampilan berpengaruh terhadap mutu kopi secara serempak, pengetahuan dan sikap berpengaruh terhadap mutu kopi secara parsial dan keterampilan tidak berpengaruh terhadap mutu kopi secara parsial.
\end{abstract}

Kata kunci: mutu kopi, keterampilan, pengetahuan, perilaku, sikap. 


\title{
BEHAVIOR OF COFFEE FARMERS IN MAKARTI UTOMO GROUP IN GENTING HAMLET GETAS VILLAGE SINGOROJO DISTRICT KENDAL REGENCY
}

\begin{abstract}
Coffee is one of Indonesia's plantation products whose marketing is of international standard, but only exported high-quality coffee. The problem that occurs in coffee commodities in Indonesia is that not all coffee farmers are able to produce high-quality coffee, so that the bargaining price of coffee is still low. One of the factors that influence coffee quality is the behavior of farmers in managing coffee farming, where the intended behavior consists of knowledge, attitudes and skills. This study aims to determine the behavior of coffee farmers and analyze the influence of the level of knowledge, attitudes and skills of farmers on the quality of coffee production in the Makarti Utomo Farmer Group. This research was conducted in October-November 2018 located in Genting Hamlet, Getas Village, Singorojo District, Kendal Regency. The research method used the survey method and all members of the farmer group were used as respondents as many as 37 farmers using the census method. Data sources were obtained from primary and secondary data. The method of data analysis uses descriptive analysis and multiple linear regression. The results of the study 1) Farmers' group Makarti Utomo have a fairly good level of knowledge, but need to be improved, the level of attitudes are good because it has good quality awareness, the level of skills in managing coffee farming is good enough but needs to be improved coffee, 2) knowledge, attitudes and skills influence the quality of coffee simultaneously, knowledge and attitudes influence the quality of coffee partially and skills do not partially affect the quality of coffee.
\end{abstract}

Keywords: attitide, behavior, coffee quality, knowledge, skills.

\section{PENDAHULUAN}

Kopi merupakan salah satu hasil perkebunan yang memegang peran penting dalam pengembangan industri perkebunan di Indonesia. Produksi kopi di Indonesia didominasi oleh perkebunan rakyat dengan luas lahan perkebunan mencapai 1.230.001 ha yang dapat menghasilkan sedikitnya 639.412 ton kopi robusta dan arabika dengan volume ekspor sebesar 502 ton. Diketahui bahwa Indonesia merupakan salah satu produsen kopi terbesar keempat di dunia setelah Brazil, Vietnam dan Kolombia (Direktorat Jenderal Pertanian, 2017).

Permasalahan yang sering terjadi pada komoditas kopi adalah produktivitas tanaman yang rendah,

https://ojs.unud.ac.id/index.php/soca terbatasnya ketersediaan benih serta kurangnya mutu kopi yang dihasilkan petani sehingga mengakibatkan rendahnya harga tawar petani di Indonesia (Direktorat Jenderal Pertanian, 2017). Faktor yang mempengaruhi produksi dan perdagangan kopi di dunia adalah aspek mutu produksi yang terdiri dari teknik budidaya hingga penanganan pasca panennya (Jaya et al, 2010). Menurut Asosiasi Eksportir Kopi Indonesia bahwa standar mutu kopi Indonesia berpedoman pada Standar Nasional Indonesia 01-2907-2008 yang bertujuan untuk menghasilkan biji kopi berkualitas baik (AEKI, 2014). Petani sebagai pelaku usahatani yang mengambil keputusan dalam perubahan usahataninya. Faktor pengambilan keputusan https://doi.org/10.24843/SOCA.2019.v13.i02.p06 
terhadap kinerja usahataninya didukung oleh perilaku petani itu sendiri meliputi pengetahuan, sikap dan keterampilan petani tersebut. Hal ini diperlukan agar petani mampu meningkatkan produktivitas dan mutu dari produk yang dihasilkan. Berdasarkan hal ini, petani dituntut harus menjadi lebih pintar agar kopi yang diproduksi bermutu baik sehingga untuk menghasilkan mutu yang baik dipengaruhi oleh perilaku petani dalam pelaksanaan budidaya kopi (Zainura et al., 2016).

Berdasarkan penelitian terdahulu yang dilakukan oleh Aklimawati et al. (2014) menunjukkan bahwa mutu biji kopi ditentukan berdasarkan mutu fisik dan citarasa kopi yang dihasilkan, serta permasalahan yang dihadapi dalam usahatani kopi. Salah satu permasalahan yang dihadapi dalam penelitian tersebut yaitu minimnya pengetahuan dan keterampilan petani tentang mutu dan budidaya kopi yang baik. Konsep yang dirujuk adalah perilaku petani berdasarkan pengetahuan dan keterampilan petani serta indikator biji kopi yang bermutu berdasarkan mutu fisik dan citarasa kopi yang dihasilkan oleh petani kopi. Didukung hasil penelitian Ramanda et al. (2016) menunjukkan bahwa kopi bermutu baik memiliki daya saing yang tinggi sehingga menguntungkan bagi para petani kopi secara produktivitas dan finansial. Menurut Hasibuan et al. (2013) bahwa kopi bermutu baik dihasilkan dari pelaksanaan Good Agricultue Practice (GAP) dan Good Manufacturing Practice (GMP) yang tepat dan sesuai dengan standar pengawasan mutu kopi yang telah ditentukan. Didukung hasil penelitian Wulandari (2018) bahwa pengendalian mutu kopi dipengaruhi oleh perilaku petani kopi dalam pelaksanaan budidaya dan pasca panen kopi, dimana konsep perilku terdiri dari perilaku aktif (tindakan) dan perilaku pasif (pengetahuan dan sikap).

Kelompok Tani Makarti Utomo merupakan kelompok tani penghasil kopi yang telah berdiri sejak tahun 1998 dan berlokasi di Desa Getas Kecamatan Singorojo Kabupaten Kendal. Desa Getas memiliki luas $17,90 \mathrm{~km} 2$ dengan jumlah penduduk sebanyak 6.724 jiwa yang terletak di lereng Gunung Srei dengan ketinggian 450 mdpl (Badan Pusat Statistik, 2017). Kelompok Tani Makarti Utomo memiliki jumlah anggota aktif sebanyak 37 petani kopi. Jenis kopi yang dibudidayakan di Kelompok Tani Makarti Utomo adalah kopi robusta dan kopi liberika, namun yang paling banyak dibudidayakan adalah kopi robusta karena kopi jenis ini lebih mudah untuk dibudidayakan. Kelompok Tani Makarti Utomo memiliki beberapa kegiatan rutin seperti pertemuan kelompok tani, royongan, penyuluhan dan pameran produk kopi yang dilaksanakan pada tahun 2002 di Kabupaten Kendal. Permasalahan yang dialami oleh Kelompok Tani Makarti Utomo adalah kinerja anggota dalam keikutsertaan kelompok tani dan kopi yang dihasilkan kelompok tani yang perlu dikaji lebih lanjut.

Penelitian ini bertujuan untuk mendeskripsikan perilaku yang dimiliki petani kopi meliputi pengetahuan, sikap dan keterampilan di Kelompok Tani Makarti Utomo, serta menganalisis pengaruh perilaku yang dimiliki petani kopi terhadap mutu produksi kopi di Kelompok Tani Makarti Utomo. Penelitian ini diharapkan mampu memberikan 
pengetahuan baru tentang pentingnya pengendalian mutu kopi yang ditentukan berdasarkan perilaku petani dalam mengelola usahatani kopinya sehingga kopi yang dihasilkan memiliki daya saing tinggi dan meningkatkan kesejahteraan petani kopi di Indonesia.

\section{METODE PENELITIAN}

Penelitian ini dilaksanakan bulan Oktober-November 2018 yang berlokasi di Dusun Genting Desa Getas Kecamatan Singorojo Kabupaten Kendal. Berikut ini merupakan kerangka pemikiran perilaku petani terhadap mutu kopi di Kelompok Tani Makarti Utomo:

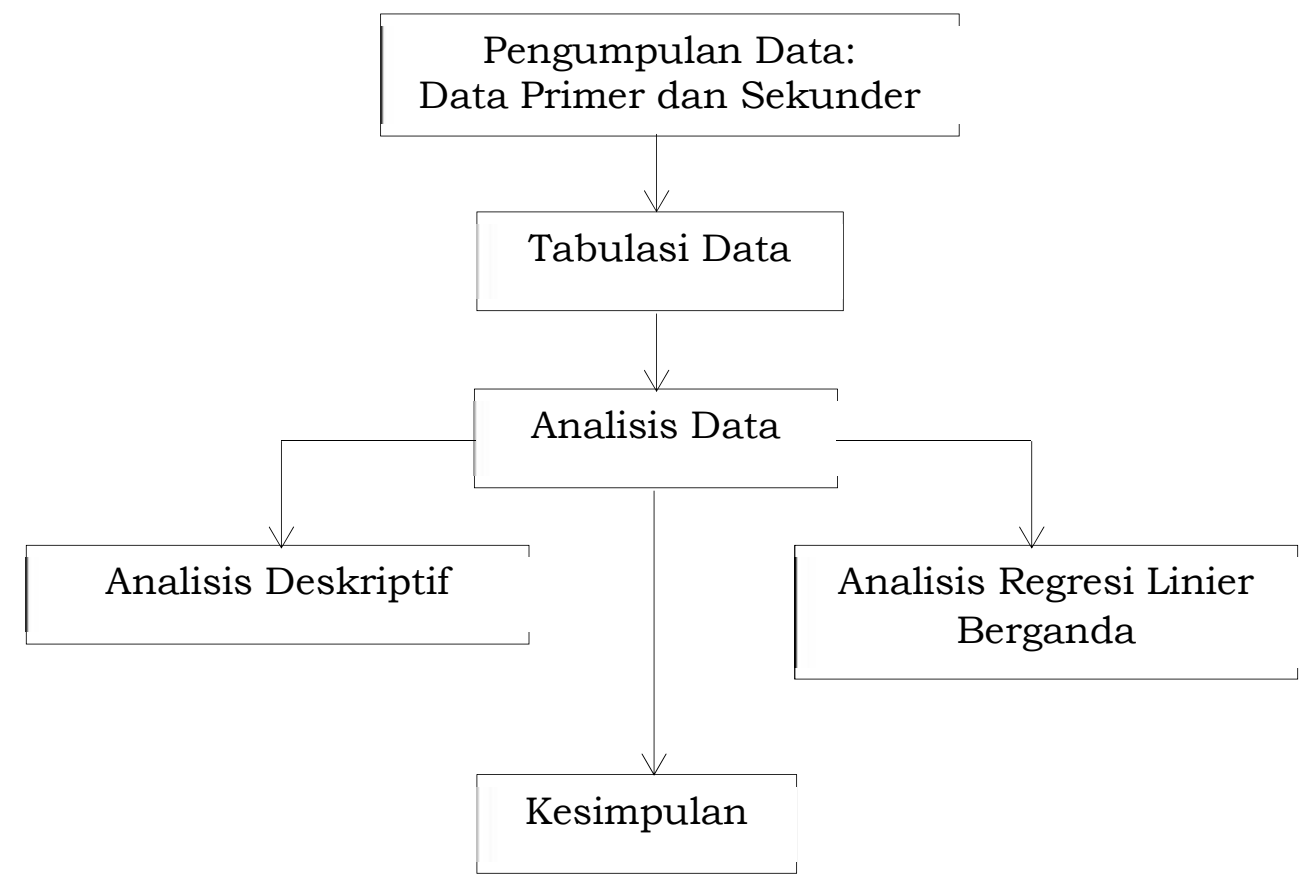

Gambar 1. Alur Metode Penelitian di Kelompok Tani Makarti Utomo

\begin{tabular}{|c|c|}
\hline Metode & (regresi atau korelasi). Jumlah \\
\hline menggunakan & \\
\hline melalui wawancara menggunakan & berdasarkan 10 kali dari \\
\hline kuesioner secara langsung kep & variabel \\
\hline Kelompok Tani Makarti & (Sugiyono, \\
\hline Penentuan & Sumber \\
\hline menggunakan & melalui \\
\hline dimana seluruh anggota Kelompok & menggunakan data primer dan da \\
\hline Tani Makarti Utomo sebanyak & sekunder. Data primer diper \\
\hline digunakan & melalui proses wawancara langsur \\
\hline penelitian. & dengan anggota Kelompok $\mathrm{Ta}$ \\
\hline seluruh anggota kelompok tani pada & Makarti Utomo melalui kuesione \\
\hline penelitian ini su & Data sekunder diperoleh dari buku, \\
\hline an $n$ & $\begin{array}{l}\text {-pihak atau instan } \\
\text { engan Kelompok Ta }\end{array}$ \\
\hline enggunakan & It \\
\hline
\end{tabular}


Data yang diperoleh kemudian ditabulasi dan dianalisis secara deskriptif dan regresi linier berganda. Analisis deskriptif dilakukan dengan cara memberikan deskripsi hasil data yang diperoleh dan diuraikan secara sistematis faktual dan akurat tentang pengaruh pengetahuan, sikap dan keterampilan terhadap mutu produksi kopi. Analisis regresi berganda digunakan untuk mengetahui apakah variabel independent (pengetahuan, sikap dan keterampilan) berpengaruh secara serempak atau parsial terhadap variabel mutu produksi kopi.

Pengukuran tingkat pengetahuan, sikap, keterampilan dan mutu kopi menggunakan skala Likert. Metode skala Likert bertujuan untuk memberikan bobot skor pada masing-masing jawaban (Sugiyono, 2011). Pemberian skor ditentukan melalui pembagian interval kelas dengan menggunakan rumus Nasution dan Barizi dalam Rambe dan Honorita (2011) yaitu sebagai berikut:

$$
\begin{gathered}
\mathrm{NR}=\mathrm{NST}-\mathrm{NSR} \\
\mathrm{PI}=\mathrm{NR}: \mathrm{JIK}
\end{gathered}
$$

Keterangan:

NR : Nilai Range

NST : Nilai Skor Tertinggi

NSR : Nilai Skor Terendah

PI : Panjang Interval

JIK : Jumlah Interval Kelas

Uji kelayakan instrumen terdiri dari dua tahap yaitu uji validitas dan uji reliabilitas. Uji validitas digunakan untuk mengetahui tingkat keandalan alat ukur atau instrumen (Ghozali, 2016). Uji reliabilitas digunakan untuk mengukur kereabilitasan kuesioner, dimana kuesioner yang reliabel memiliki jawaban konsisten setiap periode waktu (Putra et al., 2014).

Data yang telah lolos uji kelayakan instrumen selanjutnya akan diuji normalitas data. Uji normalitas digunakan untuk mengetahui apakah data berdistribusi normal atau tidak (Ghozali, 2016). Jika data berdistribusi normal, maka selanjutnya dilakukan uji parametrik berupa analisis linier berganda. Jika data tidak berdistribusi normal, maka dilakukan uji non parametrik berupa uji korelasi Spearman.

Data yang telah lolos uji normalitas kemudian dianalisis menggunakan analisis regresi linier berganda, yang bertujuan mengetahui apakah ada pengaruh tingkat pengetahuan, sikap dan keterampilan terhadap mutu produksi kopi di Kelompok Tani Makarti Utomo. Berikut ini merupakan model regresi linier berganda terhadap variabel yang diteliti (Ghozali, 2016): 


$$
\mathrm{Y}=\mathrm{a}+\mathrm{b} 1 \mathrm{X} 1+\mathrm{b} 2 \mathrm{X} 2+\mathrm{b} 3 \mathrm{X} 3+\mathrm{e}
$$

Keterangan:

$\begin{array}{ll}\mathrm{Y} & \text { : Mutu Produksi (skor) } \\ \mathrm{a} & \text { : Nilai konstanta } \\ \mathrm{b} & \text { : Nilai koefisien regresi } \\ \mathrm{e} & \text { : Error } \\ \mathrm{X} 1 & \text { : Pengetahuan (skor) } \\ \mathrm{X} 2 & \text { : Sikap (skor) } \\ \mathrm{X} 3 & \text { : Keterampilan (skor) }\end{array}$

Uji hipotesis yang pertama menggunakan uji $\mathrm{F}$, dimana uji $\mathrm{F}$ digunakan untuk mengetahui apakah variabel independen secara serempak memiliki pengaruh nyata terhadap variabel dependen (Ghozali, 2016). Uji hipotesis yang kedua menggunakan uji $t$, dimana uji $\mathrm{t}$ digunakan untuk mengetahui besarnya pengaruh variabel independen dan variabel dependen secara parsial (Ghozali, 2016).

Persamaan regresi yang telah diuji $\mathrm{F}$ dan $\mathrm{t}$ kemudian dianalisis uji koefisien determinasi untuk melihat seberapa besar variabel independent menjelaskan variabel dependent (Ghozali, 2016). Uji koefisien determinasi dapat diketahui dengan melihat nilai Adjusted R Square yang menunjukkan seberapa besar pengetahuan, sikap dan keterampilan menjelaskan mutu produksi kopi.

Uji asumsi klasik digunakan untuk mengetahui data yang digunakan telah memenuhi ketentuan dalam model regresi apakah bias atau tidak meliputi uji normalitas error, heterokedastisitas, autokorelasi dan multikolinearitas. Jika pada asumsi klasik didapatkan hasil error normal, non autokorelasi, non heterokedastisitas, dan non multikolinearitas, maka persamaan garis tidak bias (Best Linear Unbiased Estimation).

\section{HASIL DAN PEMBAHASAN}

$$
\text { Kelompok Tani Makarti }
$$
Utomo merupakan salah satu kelompok tani yang berada di Dusun Genting, Desa Getas, Kecamatan Singorojo, Kabupaten Kendal. Komoditas utama yang dihasilkan oleh kelompok tani adalah kopi robusta. Kelompok Tani Makarti Utomo telah berdiri sejak tahun 1998 dan saat ini memiliki 37 anggota aktif. Kelompok Tani Makarti Utomo terbentuk berdasarkan atas kesamaan permasalahan yang dihadapi petani di Dusun Genting di bidang produksi dan administrasi. Tujuan lain yang menjadi alasan terbentukan Kelompok Tani Makarti Utomo adalah sebagai tempat berkumpulnya anggota, meningkatkan peran pengetahuan, sikap, keterampilan dan peran petani, memudahkan komunikasi antar petani, menampung dan menyalurkan produksi dan produktivitas petani, meningkatkan potensi dan pendapatan petani serta menjadi petani yang lebih maju, mandiri dan sejahtera. 
Tabel 1. Jumlah dan Persentase Responden berdasarkan Karakteristik Responden Kelompok Tani Makarti Utomo Tahun 2019

\begin{tabular}{|c|c|c|c|}
\hline Karakteristik & Keterangan & Jumlah & Persentase \\
\hline \multirow{3}{*}{ Jenis Kelamin } & & -----orang----- & -----\%"---- \\
\hline & Pria & 22 & 59,5 \\
\hline & Wanita & 15 & 40,5 \\
\hline Total & & 37 & 100 \\
\hline \multirow[t]{4}{*}{ Umur } & $35-44$ tahun & 9 & 24,32 \\
\hline & $45-54$ tahun & 16 & 43,24 \\
\hline & $55-64$ tahun & 9 & 24,32 \\
\hline & $65-74$ tahun & 3 & 8,12 \\
\hline Total & & 37 & 100 \\
\hline \multirow{3}{*}{ Pendidikan } & SD & 26 & 70,3 \\
\hline & SMP & 7 & 18,9 \\
\hline & SMA & 4 & 10,8 \\
\hline Total & & 37 & 100 \\
\hline \multirow[t]{4}{*}{ Luas Lahan } & $\geq 0,5-1$ & 23 & 62,1 \\
\hline & $>1-2$ & 11 & 29,7 \\
\hline & $>2-3$ & 1 & 2,8 \\
\hline & $>3$ & 2 & 5,4 \\
\hline Total & & 37 & 100 \\
\hline
\end{tabular}

Sumber: Data primer penelitian yang diolah, 2019

\section{Karakteristik Responden}

Karakteristik Kelompok Tani Makarti Utomo berdasarkan jenis kelamin, responden terbanyak adalah petani dengan jenis kelamin pria. Jumlah responden pria yaitu 22 petani dengan persentase 59,5\% , sedangkan jumlah responden wanita yaitu 15 petani dengan persentase $40,5 \%$. Kegiatan yang dilakukan oleh Kelompok Tani Makarti Utomo sebagaian besar memerlukan kegiatan fisik dan berat sehingga memerlukan tenaga kerja pria yang lebih banyak. Kegiatan yang biasa dilakukan seperti pengolahan lahan, pembersihan lahan, pemberantasan gulma dan penyakit serta kegiatan pengangkutan kopi dilakukan oleh pria. Anggota kelompok tani wanita lebih banyak melakukan kegiatan pengemasan kopi dan pengolahan produk kopi serta membantu anggota kelompok tani pria dalam proses pembersihan lahan. Didukung pendapat Rahmawati dan Sunito (2013) bahwa akses kontrol dan aktivitas petani dengan jenis kelamin pria lebih besar daripada wanita karena pada dasarnya tugas utama pria adalah pencari nafkah dan penentu suatu keputusan, adanya pengaruh adat kebudayaan masyarakat yang menjadikan kurangnya melibatkan wanita dalam mengikuti suatu organisasi sehingga menyebabkan masih sedikit wanita yang bergabung dalam kelompok tani.

Karakteristik Kelompok Tani Makarti Utomo berdasarkan umur, jumlah responden paling banyak berumur 45 - 54 tahun yaitu 16 orang dengan persentase 43,24\%. Jumlah responden yang berumur 35 - 44 tahun dan 55 - 64 tahun masing-masing 9 orang dengan persentase 24,32\%. Jumlah responden paling sedikit berumur 
$65-74$ tahun yaitu 3 orang dengan persentase $8,12 \%$. Didukung Prasetia et al., dalam Rusli (2015) yang menyatakan bahwa umur produktif seseorang dalam melakukan pekerjaan adalah saat berumur 15 sampai 64 tahun. Berdasarkan hasil penelitian ditemukan hampir seluruh anggota Kelompok Tani Makarti Utomo berada dalam umur produktif yaitu berumur 35 sampai 64 tahun dengan jumlah 34 petani, sedangkan petani yang sudah tidak produktif berumur lebih dari 65 tahun berjumlah 3 petani. Umur menjadi salah satu faktor yang berpengaruh terhadap kinerja petani dalam melakukan aktivitas usahatani dan kelompok tani sebagai indikator produktif atau tidaknya petani dalam melakukan usahataninya. Anggota kelompok tani yang berumur produktif, yaitu berumur 35 hingga 64 tahun lebih banyak melakukan kegiatan fisik rutin seperti royongan dan pembersihan lahan, sedangkan anggota kelompok tani yang sudah tidak produktif, berumur $>65$ tahun lebih banyak memberi saran tentang aktivitas tani dan kegiatan usahtani.

Karakteristik Kelompok Tani Makarti Utomo berdasarkan tingkat pendidikan, jumlah petani paling banyak memiliki pendidikan terakhir SD yaitu 26 orang dengan persentase $70,3 \%$. Petani yang memiliki pendidikan terakhir SMP berjumlah 7 orang dengan persentase $18,9 \%$. Petani yang memiliki pendidikan terakhir SMA berjumlah 4 orang dengan persentase 10,8\%. Data tersebut menunjukkan bahwa tingkat pendidikan petani Kelompok Tani Makarti Utomo didominasi pada
Sekolah Dasar (SD) sehingga dapat diketahui bahwa tingkat pendidikan petani relatif rendah. Perbedaan jenjang pendidikan mempengaruhi pengetahuan, sikap dan keterampilan yang dimiliki oleh anggota Kelompok Tani Makarti utomo dalam melakukan kegiatan budidaya dan pasca panen usahatani kopinya. Sebagian besar anggota Kelompok Tani Makarti Utomo memiliki pendidikan relatif rendah dengan pendidikan terakhirnya adalah pada jenjang Sekolah Dasar (SD) sehingga dalam melaksanakan kegiatan usahataninya, sebagian besar anggota Kelompok Tani Makarti Utomo masih mengandalkan pengalaman yang diterima selama menjadi petani kopi. Menurut Budiartiningsih (2010) yang menyatakan bahwa pendidikan yang rendah akan mengakibatkan kurangnya koordinasi perencanaan dan pelaksanaan usahatani yang dijalankan oleh petani sehingga akan menyebabkan berkurangnya mutu hingga pendapatan petani.

Karakteristik Kelompok Tani Makarti Utomo berdasarkan luas lahan diketahui bahwa responden yang paling banyak memiliki luas lahan kopi sebesar $\geq 0,5-1$ ha sejumlah 23 orang dengan persentase $62,1 \%$. Responden yang memiliki luas lahan $>1-2$ ha sejumlah 11 orang dengan persentase $29,7 \%$. Responden yang memiliki luas lahan $>3$ ha sejumlah 2 orang dengan persentase 5,4\% dan paling sedikit dengan luas lahan $>2$ - 3 sejumlah 1 orang dengan persentase 2,8\%. Berdasarkan data tersebut, ratarata petani Kelompok Tani Makarti Utomo hanya memiliki luas lahan sekitar 0,5 hingga 1 ha, sehingga 
diketahui bahwa sebagian besar anggota Kelompok Tani Makarti Utomo memiliki luas lahan dalam kategori kecil/sempit. Menurut pendapat Dewi et al. (2017) yang menyatakan bahwa petani yang hanya memiliki luas lahan 0,5 hingga 1 ha menunjukkan bahwa sebagian petani masuk dalam kategori kecil dan termasuk dalam kategori lahan sempit. Didukung oleh pendapat Sajogyo (2002) yang menyatakan bahwa luas lahan mempengaruhi besar kecilnya jumlah produksi dan pendapatan yang diterimapetani nantinya, semakin besar lahan yang dimiliki petani maka jumlah produksi dan pendapatan akan besar pula dan sebaliknya. Luas lahan yang dimiliki anggota kelompok tani merupakan lahan milik pribadi yang sebagian besar kepemilikannya berdasarkan hasil warisan dari keluarga, sebagian lagi berasal dari jual beli lahan.

Tabel 2. Jumlah Responden dan Persentase berdasarkan Tingkat

Pengetahuan Kelompok Tani Makarti Utomo Tahun 2019

\begin{tabular}{ccc}
\hline Kategori & Jumlah Responden & Persentase \\
\hline Rendah & ------- Orang -------- & ------ \% ------ \\
Sedang & 9 & 64,32 \\
Tinggi & 24 & 10,86 \\
\hline Jumlah & 4 & 100
\end{tabular}

Sumber: Data primer penelitian yang diolah, 2019.

\section{Tingkat Pengetahuan Petani}

Tingkat pengetahuan

Kelompok Tani Makarti Utomo yang berada di kategori rendah sebanyak 9 petani dengan persentase $24,32 \%$. Tingkat pengetahuan Kelompok Tani Makarti Utomo yang berada di kategori sedang sebanyak 24 petani dengan persentase $64,86 \%$. Tingkat pengetahuan Kelompok Tani Makarti Utomo yang berada di kategori tinggi sebanyak 4 petani dengan persentase 10,82\%. Berdasarkan hal ini, dapat diketahui bahwa Kelompok Tani Makarti Utomo rata-rata memiliki tingkat pengetahuan dengan kategori sedang. Kategori sedang memiliki arti bahwa anggota kelompok tani memiliki pengetahuan tentang kopi yang cukup, namun perlu adanya peningkatan agar pengetahuan petani Makarti Utomo menjadi lebih baik dan maksimal tentang kopi. Pengetahuan yang diperoleh petani kopi Kelompok Tani Makarti Utomo berasal dari pendidikan formal dan nonformal, pengalaman berusahatani dan kegiatan yang dilaksanakan oleh Kelompok Tani Makarti Utomo. Hal ini didukung pendapat Yuantari et al. (2013) yang menyatakan bahwa tingkat pengetahuan suatu individu berkaitan erat dengan tingkat pengalaman dan pendidikan formalnya, semakin tinggi pengalaman dan pendidikan maka pengetahuan suatu individu akan tinggi. 
Tabel 3. Jumlah Responden dan Persentase berdasarkan Tingkat Sikap Kelompok Tani Makarti Utomo Tahun 2019

\begin{tabular}{ccc}
\hline Kategori & Jumlah Responden & Persentase \\
\hline Rendah & ------ Orang ------- & 0 \\
Sedang & 0 & 0 \\
Tinggi & 0 & 100 \\
\hline Jumlah & 37 & 100
\end{tabular}

Sumber: Data primer penelitian yang diolah, 2019.

\section{Tingkat Sikap Petani}

Tingkat sikap Kelompok Tani Makarti Utomo yang berada di kategori tinggi sebanyak 37 petani dengan persentase $100 \%$. Kategori tinggi artinya bahwa seluruh petani memiliki kesadaran yang tinggi akan pentingnya mutu produksi kopi dengan cara memberikan respon positif terhadap pengetahuan dan teknologi baru yang didapatkan oleh petani. Tingkat sikap petani Kelompok Tani Makarti Utomo yang tinggi diperoleh dari kegiatan-kegiatan yang ada dalam kelompok tani dan proses usahatani kopi yang dilakukan oleh petani sehingga memperoleh kecenderungan perilaku yang positif melalui kognisi dan perasaan petani dalam melaksanakan kegiatan usahataninya. Hal ini sesuai pendapat Astuti (2016) bahwa sikap petani diperlukan untuk mengetahui kecenderungan perilaku petani melalui kognisi dan perasaan petani terhadap sesuatu untuk melakukan suatu tindakan dalam proses usahataninya. Sikap petani kopi Makarti Utomo diperoleh dari pengalaman petani berdasarkan pengetahuan yang didapatkan oleh petani dengan mempertimbangkan dampak positif atau negatif untuk melakukan kegiatan usahataninya. Hal ini didukung pendapat Purnawanto (2010) bahwa sikap juga prediktor utama suatu individu untuk melakukan tindakan dengan mempertimbangkan segala dampak positif atau negatif.

Tabel 4. Jumlah Responden dan Persentase berdasarkan Tingkat Keterampilan Kelompok Tani Makarti Utomo Tahun 2019

\begin{tabular}{lll}
\hline Kategori & Jumlah Responden & Persentase \\
\hline & ------- Orang -------- & $------\%$------ \\
Rendah & 3 & 8,10 \\
Sedang & 30 & 81,08 \\
Tinggi & 4 & 10,82 \\
\hline Jumlah & 37 & 100
\end{tabular}

Sumber: Data primer penelitian yang diolah, 2019.

\section{Tingkat Keterampilan Petani}

Tingkat keterampilan

Kelompok Tani Makarti Utomo yang berada di kategori rendah sebanyak 3 petani dengan persentase $8,10 \%$. Tingkat keterampilan kelompok
Tani Makarti Utomo yang berada di kategori sedang sebanyak 30 petani dengan persentase $81,08 \%$. Tingkat keterampilan Kelompok Tani Makarti Utomo yang berada di kategori tinggi sebanyak 4 petani 
dengan persentase 10,82\%. Berdasarkan hal ini, dapat diketahui bahwa Kelompok Tani Makarti Utomo rata-rata memiliki tingkat keterampilan dengan kategori sedang. Tingkat keterampilan sedang memiliki arti bahwa keterampilan petani dalam melaksanakan kegiatan usahatani sudah cukup baik, namun perlu peningkatan agar petani mampu memiliki keteampilan yang lebih handal dan maksimal. Tingkat keterampilan petani kopi Kelompok Tani Makarti Utomo diperoleh berdasarkan keterampilan petani dalam melaksanakan kegiatan budidaya dan pasca panen kopi yang dihasilkan. Hal ini sesuai pendapat Hapsari et al. (2014) bahwa keterampilan petani dilihat dari kemampuan petani dalam pelaksanaan usahatani seperti pembibitan, pengendalian hama terpadu, proses pasca panen hingga kemampuan menghitung biaya usahatani serta kemampuan petani dalam pengoperasian mesin-mesin pertanian.

Tabel 5. Jumlah Responden dan Persentase berdasarkan Tingkat Mutu Produksi Kopi Makarti Utomo tahun 2019

\begin{tabular}{ccc}
\hline Kategori & Jumlah Responden & Persentase \\
\hline Rendah & $-------O r a n g ~-------$ & 13,5 \\
Sedang & 5 & 75,7 \\
Tinggi & 28 & 10,8 \\
\hline Jumlah & 4 & 100
\end{tabular}

Sumber: Data primer penelitian yang diolah, 2019.

\section{Tingkat Mutu Produksi Kopi}

Tingkat mutu produksi kopi Kelompok Tani Makarti Utomo yang berada di kategori rendah sebanyak 5 petani dengan persentase $13,5 \%$. Tingkat mutu produksi kopi Kelompok Tani Makarti Utomo yang berada di kategori sedang sebanyak 28 petani dengan persentase $75,7 \%$. Tingkat mutu produksi kopi Kelompok Tani Makarti Utomo yang berada di kategori tinggi sebanyak 4 petani dengan persentase 10,8\%. Berdasarkan hal ini, dapat diketahui bahwa Kelompok Tani Makarti Utomo rata-rata memiliki tingkat mutu produksi kopi dengan kategori sedang. Tingkat mutu kopi dengan kategori sedang memiliki arti bahwa mutu kopi yang dihasilkan oleh Kelompok Tani Makarti Utomo sudah cukup baik berdasarkan mutu fisik biji kopi beras dengan jumlah 9 cacat biji kopi. Berdasarkan penilitian yang dilakukan, biji kopi beras dan kopi sangrai yang dihasilkan Kelompok Tani Makarti Utomo memiliki cacat seperti biji kopi muda, biji pecah, biji berukuran kecil, biji berlubang satu, biji berlubang lebih dari satu, biji berwarna hitam, biji berwarna hitam sebagian dan biji berwarna coklat. Cacat biji kopi beras yang dihasilkan Kelompok Tani Makarti Utomo masih dalam batas wajar dan masih sesuai dengan Standar Nasional Indonesia. Menurut Standar Nasional Indonesia (2008) tentang biji kopi menyatakan bahwa batas normal cacat biji kopi maksimal berjumlah 11 cacat biji. Tingkat mutu produksi kopi yang dihasilkan Kelompok Tani Makarti 
Utomo dapat ditingkatkan dengan cara memperbaiki serta meningkatkan pengetahuan dan keterampilan petani dalam melaksanakan usahatani kopi.

\section{Uji Kelayakan Instrumen}

Berdasarkan olah uji validitas diperoleh hasil bahwa nilai $\mathrm{R}$ tabel dengan jumlah 37 responden sebesar 0,324. Berdasarkan nilai Corrected ItemTotal Correlation setiap item pertanyaan pada variabel pengetahuan, sikap, keterampilan dan mutu kopi adalah valid karena lebih besar dari 0324. Menurut Ghozali (2016) menyatakan bahwa jika $\mathrm{R}$ hitung lebih besar dari $\mathrm{R}$ tabel, maka data dikatakan valid. Data yang valid menunjukkan bahwa kuesioner yang digunakan sudah tepat untuk mengukur data yang seharusnya diukur.

Berdasarkan olah uji reliabilitas diperoleh hasil bahwa nilai Cronbach's Alpha variabel pengetahuan sebesar 0,786 , nilai Cronbach's Alpha variabel sikap sebesar 0,790, nilai Cronbach's Alpha variabel keterampilan sebesar 0,807 dan nilai Cronbach's Alpha variabel mutu sebesar 0,765. Berdasarkan data tersebut, diketahui bahwa seluruh variabel meliputi pengetahuan, sikap, keterampilan dan mutu adalah reliabel dengan kaidah pengambilan keputusan dengan ketentuan bahwa nilai Cronbach's Alpha lebih dari 0,07. Didukung pendapat Widarjono (2010) yang menyatakan bahwa jika suatu instrumen (kuesioner) memiliki nilai Cronbach's Alpha lebih dari 0,07, maka data tersebut dinyatakan reliabel. Ditambah pernyataan Putra et al. (2014) bahwa uji reliabilitas digunakan untuk mengukur kereabilitasan kuesioner, dimana kuesioner yang reliabel memiliki jawaban konsisten setiap periode waktu.

\section{Uji Normalitas}

Hasil uji normalitas diperoleh nilai Asymp. Sig (2-tailed) seluruh variabel memiliki nilai Asymp. Sig (2-tailed) lebih dari 0,05 yang menunjukkan bahwa seluruh data adalah normal yang terdiri dari variabel pengetahuan sebesar 0,705 , variabel sikap sebesar 0,158 , variabel keterampilan sebesar 0,973 dan variabel mutu sebesar 0,243. Berdasarkan data tersebut, diketahui bahwa seluruh variabel dalam penelitian ini memiliki distribusi data yang normal. Menurut Ghozali (2016) bahwa data dikatakan berdistribusi normal apabila nilai asymp. Sig. (2-tailed) lebih dari 0,05. Ditambah pendapat Oktaviani dan Notobroto (2014) bahwa uji normalitas merupakan uji nonparametrik yang diperlukan sebagai syarat uji multivariat dengan sebaran data sebelumnya harus berdistribusi normal.

Tabel 6. Uji Analisis Regresi Linier Berganda

\begin{tabular}{|c|c|c|c|c|c|}
\hline No & $\begin{array}{c}\text { Variabel } \\
\text { Independen }\end{array}$ & $\begin{array}{c}\text { Koefisien } \\
\text { Regresi }\end{array}$ & $\mathrm{t}$ & Sig. & Keterangan \\
\hline 1 & Pengetahuan (X1) & 0,389 & 3,581 & 0,001 & Signifikan \\
\hline 2 & Sikap (X2) & 0,595 & 3,393 & 0,002 & Signifikan \\
\hline 3 & Keterampilan (X3) & $-0,068$ & -1.097 & 0,280 & $\begin{array}{c}\text { Tidak } \\
\text { Signifikan }\end{array}$ \\
\hline
\end{tabular}




\begin{tabular}{ll}
\hline Variabel Dependen & $:$ Mutu Kopi \\
Konstanta & $:-16,213$ \\
R Square $\left(\mathrm{R}^{2}\right)$ & $: 0,658$ \\
F hitung & $: 24,078$ \\
Sig. & $: 0,000$ \\
\hline
\end{tabular}

Sumber: Data primer penelitian yang diolah, 2019.

\section{Analisis Regresi Linier Berganda}

Berdasarkan tabel 6, diketahui persamaan regresi linier berganda sebagai berikut :

$$
\begin{gathered}
\mathrm{Y}=-16,213+0,389 \mathrm{X} 1+0,595 \mathrm{X} 2- \\
0,068 \mathrm{X} 3
\end{gathered}
$$

Berdasarkan persamaan regresi linier diatas, diketahui bahwa nilai konstanta sebesar -16,213. Nilai tersebut menunjukkan apabila nilai pengetahuan, sikap dan keterampilan nilainya 0 , maka tingkat mutu kopi nilainya negatif 16,213 . Koefisien regresi pengetahuan (X1) sebesar 0,389 artinya jika pengetahuan mengalami kenaikan satu nilai, maka mutu kopi mengalami kenaikan nilai sebesar 0,389 dengan asumsi variabel independen yang lain bernilai tetap. Koefisien regresi sikap (X2) sebesar 0,595 artinya jika sikap mengalami kenaikan satu nilai, maka mutu kopi mengalami kenaikan nilai sebesar 0,595 dengan asumsi variabel independen yang lain bernilai tetap. Koefisien regresi keterampilan (X3) sebesar -0,068 artinya jika pengetahuan mengalami kenaikan satu nilai, maka mutu kopi mengalami penurunan nilai sebesar 0,068 dengan asumsi variabel independen yang lain bernilai tetap.

Uji $\mathrm{F}$ menunjukkan hasil yang signifikan, artinya bahwa secara serempak variabel independen (pengetahuan, sikap dan keterampilan) memiliki pengaruh yang nyata terhadap variabel dependen (mutu kopi) secara serempak. Didukung pendapat Widarjono (2010) bahwa variabel independen akan mempengaruhi variabel dependen secara serempak jika tingkat signifikansi $\mathrm{F}<0,05$. Menurut Ghozali (2016) uji $F$ digunakan untuk mengetahui apakah variabel independen secara serempak memiliki pengaruh nyata terhadap variabel dependen.

Hasil uji $t$ ditemukan nilai signifikansi $t$ variabel pengetahuan sebesar 0,001 < 0,05, artinya bahwa variabel pengetahuan berpengaruh terhadap mutu kopi secara parsial. Pengetahuan petani kopi di Kelompok Tani Makarti Utomo diperoleh dari pendidikan dan pengalaman yang diterima oleh masing-masing petani kopi. Pengetahuan petani tentang mutu kopi akan mempengaruhi produksi dan kualitas kopi yang dihasilkan. Didukung oleh pendapat Yuantari et al. (2013) bahwa pengetahuan menjadi salah satu dasar sebuah adopsi, dimana hal ini tergantung oleh perilaku petani mau atau tidak mau dalam penerapan adopsi tersebut.

Berdasarkan tabel 6, hasil uji t diperoleh nilai signifikansi $\mathrm{t}$ variabel sikap dari uji t sebesar 0,002 < 0,05, artinya bahwa variabel sikap berpengaruh terhadap mutu kopi secara parsial. Sikap petani kopi di Kelompok Tani Makarti Utomo dipengaruhi oleh kecenderungan petani dalam menerima atau menolak suatu adopsi, dimana adopsi dalam penelitian ini adalah pengetahuan tentang mutu produksi. Didukung pendapat Astuti (2016) bahwa sikap petani diperlukan untuk mengetahui kecenderungan perilaku petani melalui kognisi dan perasaan petani terhadap sesuatu untuk melakukan 
suatu tindakan dalam proses usahataninya.

Berdasarkan tabel 6, hasil uji t diperoleh nilai signifikansi $\mathrm{t}$ variabel keterampilan sebesar $0,280>0,05$, artinya bahwa variabel keterampilan tidak berpengaruh terhadap mutu kopi secara parsial. Hal ini terjadi karena sebagian besar petani kopi di Kelompok Tani Makarti Utomo masih kurang memahami dan belum melaksanakan adopsi secara baik, dimana adopsi yang dimaksud adalah pengetahuan tentang mutu produksi kopi. Keterampilan petani dalam melaksanakan usahatani kopi dipengaruhi oleh tingkat pengetahuan dan sikap petani serta mau atau tidaknya petani untuk mengimplementasikan pengetahuan yang didapatkan oleh petani. Didukung pendapat Putra et al. (2016) bahwa tingkat keterampilan petani dipengaruhi oleh wujud praktik dari pengetahuan dan sikap yang diperoleh, serta pemahamannya untuk melaksanakan suatu tindakan.

Hasil uji koefisien determinasi diperoleh nilai Adjusted $R$ Square sebesar 0,658, dimana angka tersebut menunjukkan besarnya pengaruh variabel independen (pengetahuan, sikap dan keterampilan) terhadap variabel dependen (mutu kopi) sebesar $65,8 \%$ dan sisanya dipengaruhi oleh variabel lain. Uji koefisien determinasi dapat dilihat dari nilai Adjusted $R$ Square, dimana nilai tersebut menunjukkan seberapa besar variabel pengetahuan, siakap dan keterampilan menjelaskan variabel mutu. Menurut Ghozali (2016) bahwa persamaan regresi yang telah diuji $\mathrm{F}$ dan diuji $\mathrm{t}$ kemudian dianalisis uji koefisien determinasi untuk melihat seberapa besar variabel independen menjelaskan variabel dependen dan variabel lain yang mempengaruhi variabel dependen.

\section{Uji Asumsi Klasik}

Berdasarkan

uji

multikolinearitas diperoleh hasil bahwa variabel pengetahuan, sikap dan keterampilan menunjukkan tidak terjadi multikolinearitas terhadap data yang diuji. Menurut Ghozali (2016) bahwa uji multikolinearitas digunakan untuk mengetahui ada atau tidaknya korelasi antar variabel bebas (independen). Berdasarkan hasil autokorelasi diperoleh hasil bahwa tidak terjadinya autokorelasi pada data yang diteliti. Menurut pendapat Nawari (2010) bahwa uji autokorelasi digunakan untuk mengetahui ada atau tidaknya hubungan antara kesalahan pengganggu pada periode $(\mathrm{t})$ dengan kesalahan pengganggu pada periode sebelumnya. Model regresi dikatakan baik apabila tidak terjadi autokorelasi dan sebaliknya. Hasil uji heterokedastisitas diperoleh bahwa titik-titik menyebar dan tidak membentuk suatu pola tertentu, dimana hal ini menandakan bahwa tidak terjadinya proses heteroskedastisitas pada model regresi. Menurut Ghozali (2016) bahwa uji heterodestisitas digunakan untuk mengetahui ada atau tidaknya variabel yang menyimpang dalam suatu model regresi.

\section{KESIMPULAN DAN SARAN}

\section{Simpulan}

Kelompok Tani Makarti Utomo memiliki tingkat pengetahuan cukup baik, tapi masih perlu ditingkatkan. Tingkat sikap sudah baik karena petani kopi memiliki kesadaran mutu yang baik. Tingkat keterampilan dalam budidaya dan pasca panen sudah cukup baik tapi perlu ditingkatkan. Tingkat mutu kopi sudah baik berdasarkan mutu fisik biji kopi.

Pengetahuan, sikap dan keterampilan memiliki pengaruh nyata terhadap mutu kopi secara serempak, 
pengetahuan dan sikap memiliki pengaruh nyata terhadap mutu kopi secara parsial dan keterampilan tidak memiliki pengaruh nyata terhadap mutu kopi secara parsial.

\section{Saran}

Sebaiknya pengetahuan dan keterampilan petani tentang budidaya dan pasca panen kopi lebih ditingkatkan, agar mutu kopi yang dihasilkan menjadi lebih baik. Meningkatkan kekompakkan dan kesadaran antaranggota Kelompok Tani Makarti Utomo dengan mengikuti semua kegiatan yang ada. Meningkatkan nilai tambah produk kopi dan memperbaiki kemasan kopi untuk mempermudah pemasaran kopi serta perlunya diadakan pengawasan mutu produksi kopi oleh lembaga yang terkait.

\section{DAFTAR PUSTAKA}

AEKI. 2014. Standar Mutu Kopi. (http://www.aekiaice.org/mutu_kopi_aeki.html). Diakses pada 26 Maret 2018.

Aklimawati, L., Yusianto dan S. Mawardi. 2014. Karakteristik mutu dan agribisnis kopi robusta di Lereng Gunung Tambora Sumbawa. J. Pelita Perkebunan. 30(2): 159-180.

Astuti, N.B. 2016. Sikap petani terhadap profesi petani: upaya untuk memahami petani melalui pendekatan psikologi sosial (kasus petani di Kecamatan Pauh Kota Padang). J. Agrisep. 16 (1): 59-66.

Badan Pusat Statistik. 2017. Kecamatan Singorojo dalam Angka 2017. BPS, Semarang.

Budiartiningsih R., Y. Maulida dan Taryono. 2010. Faktor-faktor yang mempengaruhi peningkatan pendapatan keluarga petanimelalui sektor informal di Desa Kedaburapat, Kecamatan Rangsang Barat, Kabupaten Bengkalis. J. Ekonomi. 18 (1): 79-93.

Dewi, I.N., S.A. Awang, W. Andayani dan P. Suryanto. 2017. Karakteristik petani dn kontribusi hutan kemasyarakatan terhadap pendapatan petani di Kulon Progo. J. Ilmu Kehutanan. 2 (18): 86-98.

Direktorat Jenderal Pertanian. 2014. Pedoman Teknis Budidaya Kopi Yang Baik (Good Agriculture Practices). Kementerian Pertanian, Jakarta.

Ghozali, I. 2016. Aplikasi Analisis Multivariate dengan Program SPSS. Universitas Diponegoro, Semarang.

Gujarati, D. 2010. Dasar-Dasar Ekonometrika. Salemba Empat, Jakarta.

Hapsari, H., H. Djuwendah dan A. Yusup. 2014. Pemberdayaan kelompok tani hutan melalui pengembangan agribisnis kopi. J. Aplikasi Ipteks untuk Masyarakat. 3 (2): 51-56.

Hasibuan, A.M., D. Listyati dan B. Sudjarmoko. 2013. Analisis persepsi dan sikap petani terhadap atribut benih kopi di Provinsi Lampung. Buletin RISTRI. 4(3): 215-224.

Jaya, R., Machfud dan M. Ismail. 2010. Aplikasi teknik ISM dan ME-MCDM untuk identifikasi posisi pemangku kepentingan dan alternatif kegiatan untuk perbaikan mutu kopi gayo. J. Teknologi Industri Pertanian. 21 (1): 1-8. 
Nawari. 2010. Analisis Regresi dengan MS Excel 2007 dan SPSS 17. PT. Elex Media Komputindo, Jakarta.

Oktaviani, M.A. dan H.B. Notobroto. 2014. Perbandingan tingkat konsistensi normalitas distribusi metode KolmogorovSmirnov, Lilliefors, ShapiroWilk dan Skewness-Kurtosis. J. Biometrika dan Kependudukan. 3 (2): 127-135.

Prasetia, R., T. Hasanuddin dan B. Viantimala. 2015. Perananan kelompok tani dalam peningkatan pendapatan petani kopi di Kelurahan Tugusari Kecamatan Sumberjaya Kabupaten Lampung Barat. JIIA. 3 (3): 301-307.

Purnawanto, B. 2010. Manajemen SDM Berbasis Proses. Grasindo, Jakarta.

Putra, Z.F.S., M. Sholeh dan N. Widyastuti. 2014. Analisis kualitas layanan website BTKPDIY menggunakan metode webqual 4.0. J. JARKOM. 1 (2): 174-184.

Rahmawati F. dan M.A. Sunito. 2013. Faktor-faktor yang mempengaruhi akses dan kontrol laki-laki dan perempuan dalam pengelolaan sumberdaya hutan rakyat. J. Sosiologi Pedesaan. 1 (3): 206221.

Ramanda, E., A.I. Hasyim dan D.A.H. Lestari. 2016. Analisis daya saing mutu kopi di Kecamatan Sumberjaya Kabupaten Lampung Barat. JIIA. 4 (3): 253261.

Rambe, S. S. M., dan B. Honorita. 2011. Perilaku petani dalam usahatani di lahan rawa lebak. Prosiding Seminar Nasional Budidaya Pertanian : 115-128.

Sajogyo. 2002. Sosiologi Pedesaan Kumpulan Bacaan. Tiara Wacana, Yogyakarta.

Standar Nasional Indonesia. 2008. Standar Nasional Indonesia: Biji Kopi. Kementerian Pertanian Indonesia RI, Jakarta.

Sugiyono. 2008. Metode Penelitian Kuantitatif Kualitatif dan R\&D. Alfabeta, Bandung.

Sugiyono. 2011. Statistik Untuk Penelitian. Alfabeta, Bandung.

Widarjono, A. 2010. Analisis Statistika Multivariate Terapan. UPP STIM YKPN, Yogyakarta.

Wulandari, R.A. 2018. Analisis perilaku petani kopi sertifikasi dalam mengelola risiko lingkungan di Kabupaten Tanggamus. [Skripsi]. Fakultas Pertanian Universitas Lampung, Bandar Lampung.

Yuantari, M.G.C., B. Widiarnako dan H.R. Sunoko. 2013. Tingkat pengetahuan petani dalam menggunakan pestisida di Desa Curut Kecamatan Penawangan Kabupaten Grobogan. Prosiding Seminar Nasional Pengelolaan Sumberdaya dan Lingkungan. Program Pasca Sarjana. Universitas Diponegoro, Semarang.

Zainura, U., N. Kusnadi., Burhanuddin. 2016. Perilaku kewirausahawan petani kopi arabika gayo di Kabupaten Bener Meriah Provinsi Aceh. J. Penyuluhan. 12 (2): 126-143. 